\title{
geosciences
}

ISSN 2076-3263

www.mdpi.com/journal/geosciences

Article

\section{Bythocythere solisdeus n. sp. and Cytheropteron eleonorae n. sp. (Crustacea, Ostracoda) from the Early Pleistocene Bathyal Sediments of Cape Milazzo (NE, Sicily)}

\section{Francesco Sciuto}

Palaeoecological Research Group, Earth Science Section, Department of Biological, Geological and Environmental Science, Catania University, Corso Italia, 55, Catania 95129, Italy;

E-Mail: fsciuto@unict.it; Tel.: +0039-957195761; Fax:+0039-95719737

Received: 21 May 2012; in revised form: 19 June 2012 / Accepted: 29 June 2012 /

Published: 9 July 2012

\begin{abstract}
Two new fossil species of Ostracoda belonging to the genus Bythocythere Sars, 1866, Bythocythere solisdeus n. sp. and to the genus Cytheropteron Sars, 1866, Cytheropteron eleonorae n. sp. are described. The specimens come from the upper silty sand layers of the Globorotalia truncatulinoides excelsa Zone ("Sicilian" stage), cropping out in "Cala S. Antonino" along the western side of the Cape Milazzo Peninsula (NE Sicily). Both species belong to a typical Bathyal ostracod association characterized by very low temperatures.
\end{abstract}

Keywords: marine ostracods; new species; Early Pleistocene; bathyal; Sicily

\section{Introduction}

Discontinuous lenses of yellowish and greyish fine sands and silts crop out along the steep slopes of the Cape Milazzo Peninsula (NE Sicily) (Figure 1). The sandy-silty sedimentary succession (Figure 2) rests unconformably on shallow-water Messinian limestones or directly on the metamorphic basement of the Calabrian Complex and is truncated upwards by the Tyrrhenian erosive surface locally draped by a thin layer of polygenic conglomerates. The sedimentary sequence is capped by Aeolian volcanic ashes.

The sands and silts were deposited largely during the Gelasian Stage (Early Pleistocene) and partly during the Sicilian Stage [1-6] in epibathyal environments as testified by brachiopod [7], bryozoan [8], foraminifer [1] and ostracod associations [4-6,9]. At Cala S. Antonino the ostracod fauna of the Lower Gelasian layers is characterized by Bythocypris obtusata, Henryhowella sarsi profunda, Bairdoppilata 
profunda, Costa tricostata pliocenica, and also by Quasibuntonia radiatopora and Agrenocythere pliocenica [4]. The latter two species are listed among the psychrospheric ostracods by Benson [10].

Figure 1. Geographical location of the Cape Milazzo Peninsula and Cala S. Antonino with the sandy-silty succession (marked by arrows).

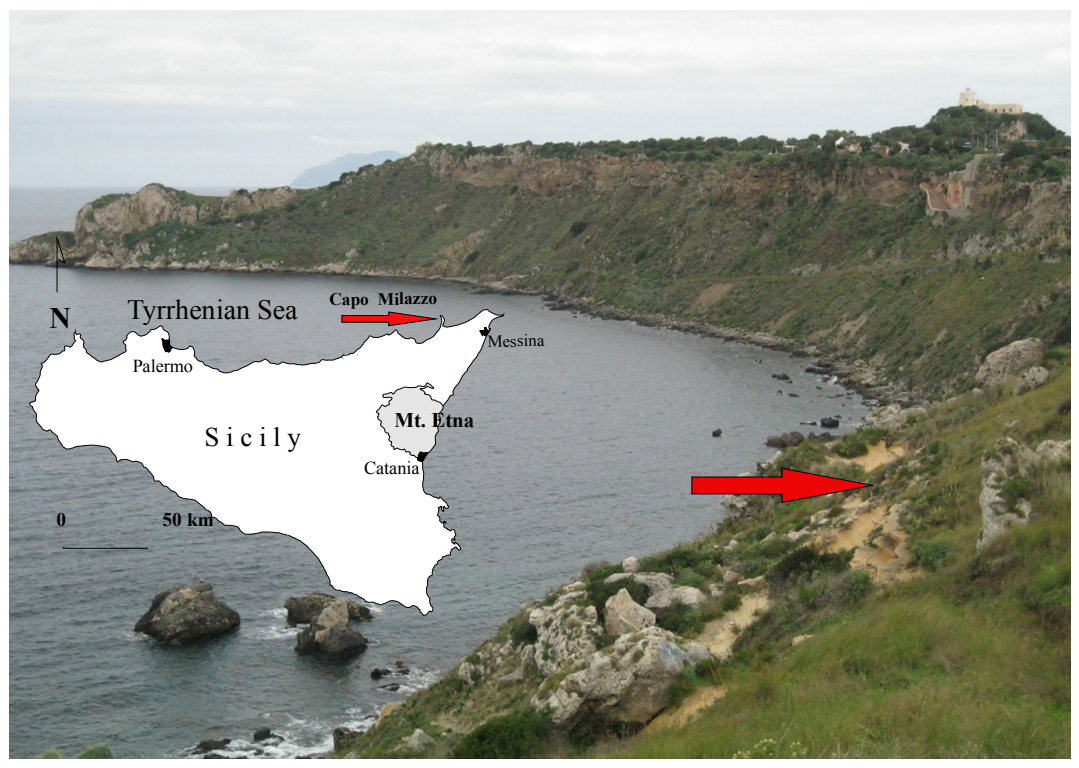

The upper layers can be ascribed to the Sicilian Stage owing to the presence of Hyalinea baltica and Globorotalia truncatulinoides excelsa. Samples from these layers (Figure 2) are characterised by a significant increase in ostracod specific diversity in relation to underlaying layers [5]. Few species constitute the bulk of the association whereas several species are represented by a few or a single specimen (Table 1).

Figure 2. The mid-upper part of the sandy-silty sedimentary succession cropping out at Cala S. Antonino. (a) with the "Sicilian" greyish sandy layers marked by the arrow and (b) the corresponding Log.
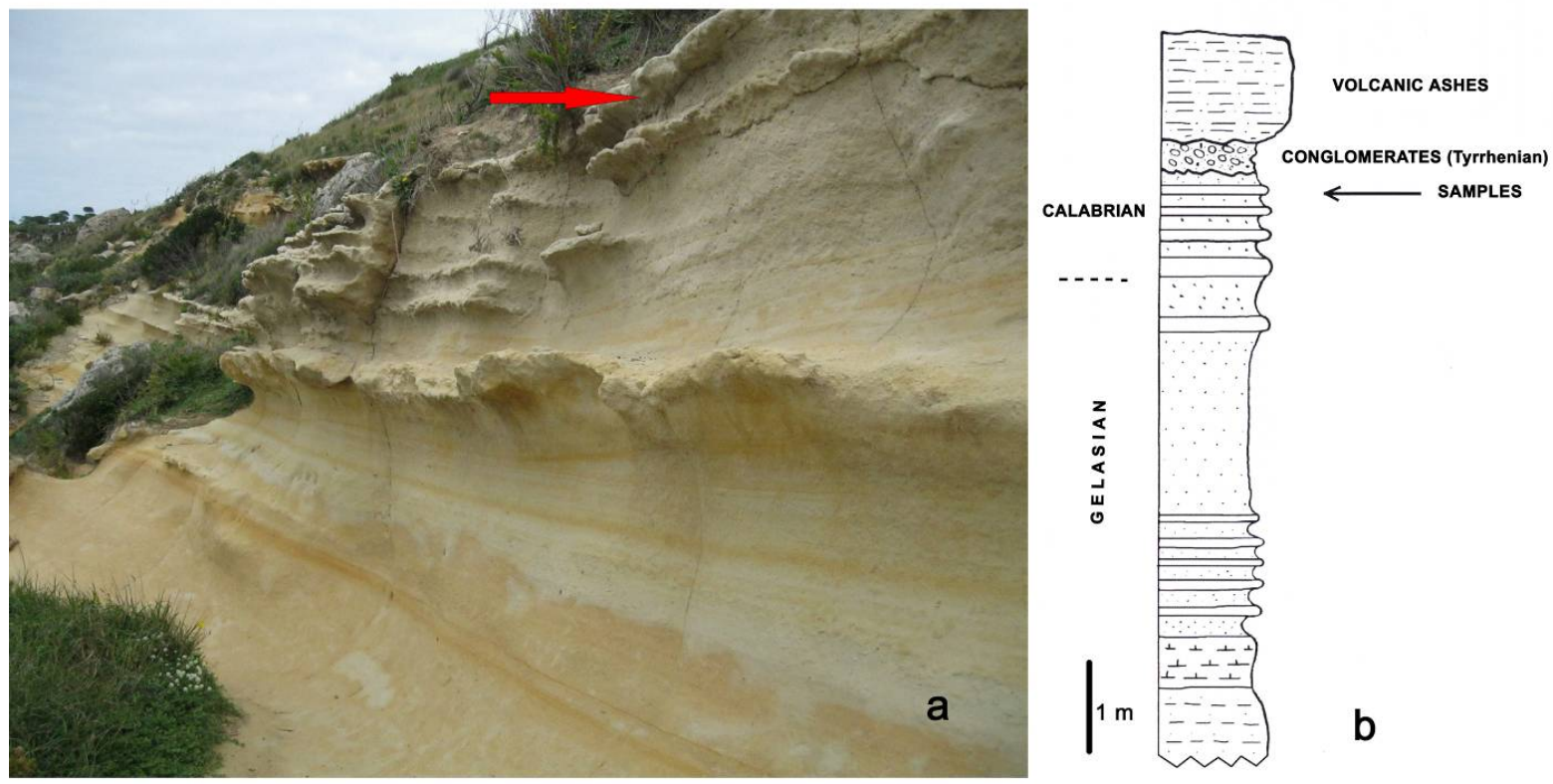
Table 1. List of the ostracod species (in order of abundance) collected in the samples from Cala S. Antonino.

\begin{tabular}{|c|c|c|c|c|c|}
\hline OSTRACOD SPECIES & n. spec. & $\%$ & OSTRACOD SPECIES & n. spec. & $\%$ \\
\hline Bythocypris obtusata (SARS) & 45 & 19.31 & Eucythere curta RUGGIERI & 2 & 0.86 \\
\hline Bairdia conformis (TERQUEM) & 25 & 10.73 & Paracytherois spp. & 2 & 0.86 \\
\hline Cytherella vulgatella AIELLO et al. & 20 & 8.58 & Paradoxostoma spp. & 2 & 0.86 \\
\hline Henryhowella sarsii profunda BONADUCE et al. & 20 & 8.58 & Pontocypris acuminata (MUELLER) & 2 & 0.86 \\
\hline Cytheropteron eleonare $\mathrm{n} . \mathrm{sp}$. & 17 & 7.30 & Pseudocythere armata BONADUCE et al. & 2 & 0.86 \\
\hline Bythocythere solisdeus n. sp. & 8 & 3.43 & Argilloecia acuminata MUELLER & 1 & 0.43 \\
\hline Pseudocythere caudata SARS & 7 & 3.00 & Argilloecia micra BONADUCE et al. & 1 & 0.43 \\
\hline Krithe compressa (SEGUENZA) & 7 & 3.00 & Argilloecia robusta BONADUCE et al. & 1 & 0.43 \\
\hline Bythocypris bosquetiana (BRADY) & 6 & 2.58 & Aurila lanceaeformis* ULICZNY & 1 & 0.43 \\
\hline Cytheropteron lancei CARBONEL & 6 & 2.58 & Cytheropteron bifidum COLALONGO \& PASINI & 1 & 0.43 \\
\hline Krithe spp. & 6 & 2.58 & Cytheropteron pinarense gillesi AIELLO et al. & 1 & 0.43 \\
\hline Anchistrocheles interrupta AIELLO et al. & 5 & 2.15 & Cytheropteron pseudoalatum COLALONGO \& PASINI & 1 & 0.43 \\
\hline Cytheropteron ionicum COLALONGO \& PASINI & 5 & 2.15 & Cytheropteron testudo SARS & 1 & 0.43 \\
\hline Sclerochilus gr. contortus (NORMAN) & 5 & 2.15 & Eucythere $\mathrm{cf}$. E. triangula WHATLEY \& COLES & 1 & 0.43 \\
\hline Aurila impressa* RUGGIERI & 4 & 1.72 & Eucytherura sp. & 1 & 0.43 \\
\hline Cytheropteron pinnatum COLALONGO \& PASINI & 3 & 1.29 & Heterocythereis albomaculata* (BAIRD) & 1 & 0.43 \\
\hline Sclerochilus spp. & 3 & 1.29 & Macrocypris sp. & 1 & 0.43 \\
\hline Krithe frutex ABATE et al. & 3 & 1.29 & Paijenborchella malaiensis cymbula RUGGIERI & 1 & 0.43 \\
\hline Aurila spp.* & 2 & 0.86 & Pedicythere phryne BONADUCE et al. & 1 & 0.43 \\
\hline \multicolumn{6}{|l|}{ Bythoceratina scaberrima BENSON \& SILV.- } \\
\hline BRADLEY & 2 & 0.86 & Profundobythere sp. & 1 & 0.43 \\
\hline Cytheropteron $\mathrm{cf}$. C. venustum BONADUCE et al. & 2 & 0.86 & Quasibuntonia radiatopora (SEGUENZA) & 1 & 0.43 \\
\hline Cytheropteron circumactum COLALONGO \& PASINI & 2 & 0.86 & Tenedocythere prava* (BAIRD) & 1 & 0.43 \\
\hline \multirow[t]{2}{*}{ Cytheropteron triangulum COLALONGO \& PASINI } & 2 & 0.86 & Typhloeucytherura calabra COLALONGO \& PASINI & 1 & 0.43 \\
\hline & & & Total & 233 & 100.00 \\
\hline
\end{tabular}

Note: n. spec. $=$ number of specimens (abundance); $\%=$ percentage $($ dominance $) ;=$ allochthonous species. 
Some specimens found in these samples cannot be assigned to any of the already known ostracod species. The aim of this paper is to describe these new species. They belong to the genera Bythocythere Sars, 1866 and Cytheropteron Sars, 1866.

Specimens were examined and measured under a LMU Tescan Vega II scanning electron microscops (SEM).

Material is housed in the Paleontological Museum of the Catania University (PMC).

\section{Systematics}

Class Ostracoda Latreille, 1806

Order PoDOCOPIDA Sars, 1866

Family BYTHOCYTHERIDAE Sars, 1866

Genus Bythocythere Sars, 1866

Bythocythere solisdeus n. sp.

Figure $3(\mathrm{a}-\mathrm{g})$

Derivatio nominis-From "Peninsula of the sun god", the legendary name of the Cape Milazzo Peninsula.

Holotype - A right valve $(\mathrm{L}=560 \mu \mathrm{m} ; \mathrm{H}=355 \mu \mathrm{m} ; 1=215 \mu \mathrm{m})$ (Figure 3a) (PMC.O5H.25.04.2012).

Paratypes - Two left valves and two right valves (Figure 3(b,d,f,g)) (PMC.O18-21P.25.04.2012). Further six right valves and five left valves, not shown in the figure, from the same sample.

Type locality - "Cala S. Antonino" along the western side of the Cape Milazzo Peninsula (Tav. Milazzo, F.253 IV SO, 38 $15^{\prime} 52^{\prime \prime}$ N, 15¹4'10" E). Upper silty-sandy layers.

Stratigraphic Range-Sicilian Stage (Globorotalia truncatulinoides excelsa Zone).

Diagnosis - Bythocythere solisdeus n. sp. is characterized by a wide central area of the carapace, strongly elevated and inflated, a postero-ventrally swell; helmet-shaped carapace in dorsal view, with flat central area and wide flattened anterior and posterior marginal areas.

Description - Carapace medium-sized, subrhomboidal in lateral view.

Anterior margin regularly arched. Dorsal margin long and straight. Ventral margin sinuous, with a light oral convexity anteriorly, and regularly and steeply bending posteriorly. Posterior margin asymmetrically rounded, more pronounced towards the dorsal side, lacking a caudal process, as can be observed on the holotype. Nevertheless, this part of the carapace seems to be particularly fragile as several specimens show a broken postero-dorsal area.

Anterior and posterior marginal area flattened and wide.

Central area of the valves strongly elevated, inflated and postero-ventrally swelled and folded down (Figure 3a,b,f,g).

Carapace helmet-shaped in dorsal view with somewhat flattened central area connected to the marginal areas through steep posterior and anterior areas (Figure $3 \mathrm{~g}$ ).

Outer surface pitted and reticulated. Circular pits numerous, large, well marked especially in the swollen part of the carapace and longitudinally aligned in the ventral area. Polygonal reticulum, barely 
visible through the stereomicroscope, slight in the dorsal, marginal and central areas and more marked in the postero-ventral area where longitudinal elements are particularly obvious.

Few normal pore-canals, small, simple and visible in the centro-dorsal area of the carapace (Figure 3e). Inner lamella anteriorly and postero-ventrally wide; vestibula narrow anteriorly, wide in the postero-dorsal area (Figure 3d). Marginal pore-canals relatively numerous, simple, short and restricted to the anterior margin (Figure 3d).

Eye tubercles absent.

Hinge lophodont: a straight groove parallel to the dorsal margin with two little simple teeth at the anterior and posterior extremities in the right valve; left valve complementary (Figure 3d).

Muscle scars barely visible, even under stereomicroscope with transmitted light. Five separated adductor muscle scars (Figure 3c) aligned in a single arcuate row. A sixth scar higher up and away from the other ones. Two barely visible frontal scars.

Remarks - The new species has been assigned to Bythocythere Sars using the central muscle scars and the lophodont hinge.

Bythocythere solisdeus $\mathrm{n}$. sp. is distinguishable from all other species within the genus because of the wide and strongly flattened anterior and posterior marginal area and the central part of the carapace strongly inflated and ventro-posteriorly folded down.

B. solisdeus n.sp. shows some affinities with Bythocythere mylaensis, described by Sciuto from the Lower Pleistocene bathyal sediments of "Punta Messinese" (Milazzo) [6]. Both species show an inflated central part of the carapace, flattened marginal areas and a comparable ornamentation. Nevertheless, some differences are obvious and justify the erection of a new species. B. solisdeus $\mathrm{n}$. sp. has the inflated central area of the carapace more extensive than B. mylaensis and flattened, in spite of regularly rounded. The swollen central area is also ventro-posteriorly folded down, whereas such folds are absent in B. mylaensis. Furthermore, B. solisdeus n. sp. shows a steeper outline of the anterior and posterior ends in dorsal view. Noteworthy, B. solisdeus $\mathrm{n}$. sp. completely lacks the ripples on the inner side of the postero-ventral marginal area and the acute caudal process that characterize B. myalaensis. Lastly, the new species has carapace sizes larger than B. mylaensis (Table 2). Morphological affinities between B. mylaensis and B. solisdeus could suggest a case of sexual dimorphism. Nevertheless, the two species have never been found together in the same sample/site and stratigraphic level. Furthermore, a male specimen of B. mylaensis has been recently detected (specimen figured in Sciuto [9]) in addition to the female ones previously recorded [6]. Juveniles not found.

Family CYTHERURIDAE Müller, 1894

Genus Cytheropteron Sars, 1866

Cytheropteron eleonorae $\mathrm{n}$. sp.

Figure $3(\mathrm{~h}-\mathrm{n})$

Derivatio nominis - From Lady Eleonora Baeli, a young noblewoman who lived in Milazzo during the XVII century.

Holotype-A right valve $(\mathrm{L}=600 \mu \mathrm{m} ; \mathrm{H}=405 \mu \mathrm{m} ; 1=185 \mu \mathrm{m})$ (Figure 3(h)) (PMC.O6H.25.04.2012).

Paratypes - One left valve and two right valves (Figure 3i,m,n) (PMC.O22-24P.25.04.2012). Further 12 right and 17 left valves, not shown in the figure, from the same sample. 
Type locality - "Cala S. Antonino" along the western side of the Cape Milazzo Peninsula (Tav. Milazzo, F.253 IV SO, 38 $15^{\prime} 52^{\prime \prime} \mathrm{N}, 15^{\circ} 14^{\prime} 10^{\prime \prime}$ E). Upper silty-sandy layers.

Stratigraphic Range - Sicilian Stage (Globorotalia truncatulinoides excelsa Zone).

Diagnosis-Cytheropteron eleonorae n. sp. is characterized by an extended and arched alar process.

Description-Carapace medium-sized, subovate in lateral view. Valves asymmetric. RV overlapping LV dorsally. Anterior margin rounded, dorsal margin arched and convex in RV, more flattened in LV. The dorsal margin passes to the caudal process, situated in the central posterior area, through a weak hump. Caudal process slightly acute and prominent. Ventral margin sinuous with a light oral convexity anteriorly. Dorsal ridge marked but not prominent, parallel to the dorsal margin.

Alar process wide, flat and extended from the antero-ventral to the postero-ventral margin, with a general rounded outline in dorsal view, joined to the anterior margin through a gentle bend, and posteriorly truncated (Figure $3 \mathrm{~m}$ ).

Outer surface finely punctated and ornamented by slight and braided ridges, more marked in the posterior area where a clear reticulum arises, and less obvious in the anterior area. Ridges formed and/or bounded by evenly spaced, aligned puncta; further puncta, organized in nearly parallel rows, fill the in intermediate spaces, more densely spaced in the alar process and in the posterior area (Figure 3h,i). Some valves show a certain variability in the distribution and density of puncta.

Simple normal pore canals.

Inner lamella wide anteriorly, narrow postero-ventrally. Vestibula present: the anterior one large, the posterior one narrow (Figure 3n). Marginal pore canals not visible.

Hinge entomodont (Figure 3n).

Four adductor muscle scars aligned in a single straight row; two frontal scars, one larger than the other, kidney-shaped (Figure 31).

Remarks - The new species has been assigned to the genus Cytheropteron using the type of hinge, the characteristic muscle scars and the general shape of the carapace. The braided structure of the ornamentation distinguishes it from the other species of the genus.

No evidence of sexual dimorphism. Several juvenile specimens are present. 
Figure 3. (a-g) Bythocythere solisdeus n. sp.: (a) Right valve in lateral view (scale bar $100 \mu \mathrm{m}$ ); (b) Left valve in lateral view (scale bar $100 \mu \mathrm{m}$ ); (c) Muscle scars (drawing); (d) Right valve, internal view (scale bar $200 \mu \mathrm{m}$ ); (e) Normal pores; (f) Left valve in ventral view (scale bar $100 \mu \mathrm{m}$ ); (g) Right valve in dorsal view (scale bar $100 \mu \mathrm{m}$ ); (h-n) Cytheropteron eleonorae n. sp.: (h) Right valve in lateral view (scale bar $200 \mu \mathrm{m}$ ); (i) Left valve in lateral view (scale bar $200 \mu \mathrm{m}$ ); (I) Muscle scars (drawing); (m) Right valve in dorsal view (scale bar $100 \mu \mathrm{m}$ ); (n) Right valve, internal view (scale bar $100 \mu \mathrm{m}$ ).

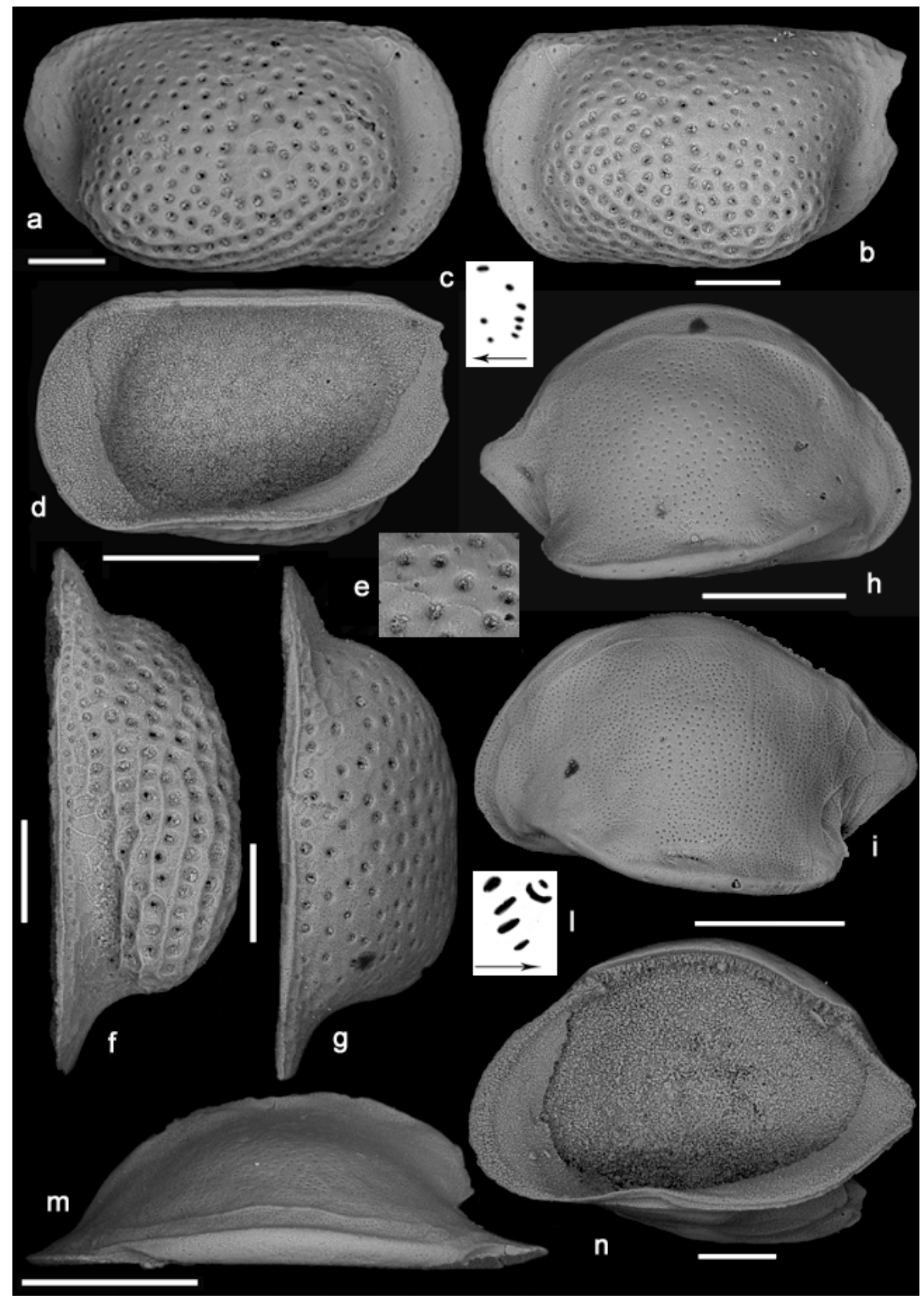


Table 2. Size of B. solisdeus and C. eleonorae.

\begin{tabular}{cccc|cccc} 
& \multicolumn{3}{c|}{ Bythocythere solisdeus n. sp. } & & \multicolumn{3}{c}{ Cytheropteron eleonorae n. sp. } \\
\cline { 2 - 4 } \cline { 6 - 7 } & $\mathrm{L}$ & $\mathrm{H}$ & $\mathrm{L} / \mathrm{H}$ & & $\mathrm{L}$ & $\mathrm{H}$ & $\mathrm{L} / \mathrm{H}$ \\
\hline LV & 560 & 355 & 1.577465 & $\mathrm{LV}$ & 623.27 & 396.47 & 1.572048 \\
LV & 538.31 & 298.39 & 1.804048 & $\mathrm{LV}$ & 662.66 & 405.77 & 1.633093 \\
LV & 575.31 & 316.71 & 1.81652 & $\mathrm{LV}$ & 627.89 & 396.27 & 1.5845 \\
LV & 547.81 & 308.24 & 1.777219 & $\mathrm{RV}$ & 661.84 & 396.62 & 1.668701 \\
RV & 577.33 & 327.14 & 1.76478 & $\mathrm{RV}$ & 600 & 405 & 1.481481 \\
RV & 580.47 & 332.14 & 1.747667 & $\mathrm{RV}$ & 658.92 & 428.57 & 1.537485 \\
RV & 575.24 & 336.02 & 1.711922 & $\mathrm{RV}$ & 668.72 & 410.18 & 1.630309 \\
RV & 584.29 & 343.01 & 1.70342 & & & & \\
Mean LV & 555.3575 & 319.585 & & & 637.94 & 399.5033 & \\
Mean RV & 579.3325 & 334.5775 & & & 647.37 & 410.0925 & \\
& & & & & & & \\
LV & 15.99205 & 24.76843 & & & 21.53242 & 5.428014 & \\
RV & 3.942473 & 6.694417 & & & 31.8461 & 13.52612 & \\
\hline
\end{tabular}

Note: $\mathrm{L}(\mu \mathrm{m})=$ length, $\mathrm{H}(\mu \mathrm{m})=$ height, $\delta=$ standard deviation, $\mathrm{LV}=$ Left valve, $\mathrm{RV}=$ Right valve.

\section{Discussion and Conclusions}

The ostracod fauna associated to the species described here as new shows composition and structure indicative of Bathyal environments [11,12] (inter alias). Only four ostracod species (Table 1), namely Bythocypris obtusata, Bairdia conformis, Cytherella vulgatella and Henryhowella sarsii profunda, are dominant. The several other species, namely B. bosquetiana Brady, Bairdia conformis (Terquem), Sclerochilus contortus (Norman), Pseudocythere caudata, Cytheropteron ionicum and Anchistrocheles interrupta Aiello et al. that follow account for only $18 \%$ of the entire association. In contrast, most species (about 70\%), including B. scaberrima, Q. radiatopora and C. testudo, are represented by few specimens [5]. This ostracod association, dating back to the upper part of the Sicilian Stage, presumably lived in bathyal environments located presumably deeper than $600 \mathrm{~m}$ [4-6]. This inference is congruent with the general mean uplift rate of about $1-1.1 \mathrm{~mm} / \mathrm{a}$ estimated by Catalano and Di Stefano [13] and Antonioli et al. [14] for the area in the last $600 \mathrm{ka}$.

Noteworty, the fossil association contains some taxa whose distribution seems to be strongly influenced by temperature rather than by other factors. These species are $B$. scaberrima, Q. radiatopora, C. testudo, and probably also B. obtusata and B. mylaensis [6]. The first two species are indicated as psychrospheric by Benson [10]. Analogously, C. testudo can be considered as a stenothermic species restricted to very cold waters, independently of the depth, taking into account data on both its recent (Stepanova et al. [15], Dingle and Lord [12] and Swanson and Ayress [16]) and fossil distribution (Whatley and Coles [17], Aiello et al. [18] and Montcharmont-Zei et al. [19]). Similarly, B. obtusata has been reported from Norwegian and British coasts between 145 and $165 \mathrm{~m}$ water depth by Sars [20] and in the recent Mediterranean Sea at depths between 150 and $2905 \mathrm{~m}$ by Puri et al. [21]. Finally, B. mylaensis originates from sediments sampled at $745 \mathrm{~m}$ depth in the Northern Ionian Sea dating from the post Würmian acme [22].

Consequently, assuming that both new species became fossilized in situ (assumption best supported for $C$. eleonorae n. sp. exhibiting a population structure, including specimens at different life stages) and taking into account the context in which they were found and the environmental requirements 
pointed out by the association as a whole, it can be hypothesized that Bythocythere solisdeus n. sp. and Cytheropteron eleonorae n. sp. lived in deep bathyal environments characterized by about this statement, as presently the two new species are known from a single site in sediments of the Pleistocene (Sicilian Stage) in the central Mediterranean area.

\section{Acknowledgments}

I thank A. Rosso (University of Catania) for discussions and suggestions. Thanks are also due to David J. Horne (School of Geography Queen Mary, University of London) and to the other two anonymous referees. The SEM photos were taken by Alfio Viola (University of Catania).

\section{References}

1. Violanti, D.I. Foraminiferi plio-pleistocenici di Capo Milazzo. Boll. Mus. Reg. Sc. Nat. T. 1988, 6, 359-392.

2. Fois, E. La successione neogenica di Capo Milazzo (Sicilia nord-orientale). Riv. Ital. Paleontol. S. 1990, 95, 397-440.

3. Fois, E. Stratigraphy and palaeogeography of the Capo Milazzo area (NE Sicily, Italy): Clues to the evolution of the southern margin of the Tyrrhenian Basin during the Neogene. Palaeogeogr. Palaeoclimatol. Palaeoecol. 1990, 78, 87-108.

4. Sciuto, F. Dati preliminari sulla ostracofauna pliocenica di Capo Milazzo (Sicilia NE). Boll. Soc. Paleontol. I. 2003, 42, 179-184.

5. Sciuto, F. Ostracodi batiali pleistocenici di Capo Milazzo (Sicilia NE) ed implicazioni paleoambientali. Rend. Soc. Paleontolol. I. 2005, 2, 219-227.

6. Sciuto, F. Bythocythere mylaensis n. sp. (Crustacea, Ostracoda) from Early Pleistocene of Capo Milazzo (NE Sicily). Boll. Soc. Paleontol. I. 2009, 48, 183-188.

7. Gaetani, M.; Saccà, D. Brachiopodi batiali del Pliocene e del Pleistocene di Sicilia e Calabria. Riv. Ital. Paleontol. S. 1984, 90, 407-458.

8. Rosso, A. Terataulopocella borealis gen. et sp. nov., a deep-water Pliocene Lekythoporid (Briozoa) from the Mediterranean Area. Mem. Sc. Geol. 2002, 54, 65-72.

9. Sciuto, F. New ostracod species from Lower Pleistocene Bathyal sediments of Capo Milazzo (NE, Sicily). Boll. Soc. Paleontol. I. 2012, in submit.

10. Benson, R.H. Ostracodes as indicators of threshold depth in the Mediterranean during the Pliocene. In The Mediterranean Sea: A Natural Sedimentation Laboratory; Stanley, D.J., Ed.; Stroudsburg, PA, USA, 1972; pp. 63-73.

11. Benson, R.H. Estimating greater paleodepths with ostracodes, especially in past thermospheric oceans. Palaeogeogr. Palaeoclimatol. Palaeoecol. 1984, 48, 107-141.

12. Dingle, R.V.; Lord, A.R. Benthic ostracods and deep water-masses in the Atlantic Ocean. Palaeogeogr. Palaeoclimatol. Palaeoecol. 1990, 80, 213-235.

13. Catalano, S.; Di Stefano, A. Sollevamenti e tettogenisu pleistocenica lungo il margine tirrenico dei Monti Peloritani: Integrazione dei dati geomorfologici, strutturali e biostratigrafici. Il Quaternario 1997, 10, 337-342. 
14. Antonioli, F.; Kershaw, S.; Renda, P.; Rust, D.; Belluomini, G.; Cerasoli, M.; Radtke, U.; Silenzi, S. Elevation of the last interglacial highstand in Sicily (Italy): A benchmark of Coastal tectonic. Quarter. Int. 2006, 145-146, 3-18.

15. Stepanova, A.; Taldenkova, E.; Bauch, H.A. Recent ostracoda from Laptev Sea (Arctic Siberia): species assemblages and some environmental relationships. Mar. Micropaleontol. 2003, 48, 23-48.

16. Swanson, K.M.; Ayress, M.A. Cytheropteron testudo and related species from SW Pacific with analyses of their soft anatomics, relationships and distribution. Senck. Biol. 1999, 79, 151-193.

17. Whatley, R.; Coles, G. The late Miocene to Quaternary Ostracoda of Leg 94, Deep Sea Drilling Project. Rev. Esp. Micropaleont. 1987, 19, 33-97.

18. Aiello, G.; Barra, D.; Bonaduce, G. The genus Cytheropteron Sars, 1866 (Crustacea: Ostracoda) in the Pliocene-Early Pleistocene of the Mount San Nicola Section (Gela, Sicily). Micropaleontology 1996, 42, 167-178.

19. Moncharmont-Zei, M.; Russo, B.; Sgarrella, F.; Bonaduce, G.; Mascellaro, P. Paleoclimatic record from 4 cores (Gulf of Taranto, Ionian Sea). Evidence from Foraminifera and Ostracoda. Boll. Soc. Paleontol. I. 1985, 23, 21-51.

20. Sars, G.O. An account of the Crustacea of Norway Vol. IX: Ostracoda; Bergen Museum: Oslo, Norway, 1928.

21. Puri, H.S.; Bonaduce, G.; Gervasio, A.M. Distribution of Ostracoda in the Mediterranean. In The Taxonomy, Morphology and Ecology of Recent Ostracoda; Neale, J.W., Ed.; Lubrecht \& Cramer Ltd.: Edinburgh, UK, 1969; pp. 358-411.

22. Malinverno, E.; Taviani, M.; Rosso, A.; Violanti, D.; Villa, I.; Savini, A.; Vertino, A.; Remia, A; Corselli, C. Stratigraphic framework of the Apulian deep-water coral province, Ionian Sea. Deep Sea Res. Pt. II Trop. Stud. Oceanogr. 2010, 57, 345-359.

(C) 2012 by the authors; licensee MDPI, Basel, Switzerland. This article is an open access article distributed under the terms and conditions of the Creative Commons Attribution license (http://creativecommons.org/licenses/by/3.0/). 